\title{
Jonassen model in the development of integrative projects
}

\section{Modelo Jonassen en el desarrollo de proyectos integradores}

QUEZADA-ARGUIJO, Alondra Jacquelinne†, POZAS-CÁRDENAS, Mariano Javier, CURIELANAYA, Arturo and HERNÁNDEZ-SÁNCHEZ, David

Universidad Autónoma del Estado de Hidalgo, Academic Area of Computing and Electronics, Mexico.

ID $1^{\text {st }}$ Author: Alondra Jaquelinne, Quezada-Arguijo / ORC ID: 0000-0003-3534-6709, Researcher ID Thomson: AAR2817-2021, CVU CONACYT ID: 1136006

ID $1^{\text {st }}$ Co-author: Mariano Javier, Pozas-Cárdenas / ORC ID: 0000-0003-3502-7740, Researcher ID Thomson: P-67192018, arXiv Author ID: X_mpozas89018,

ID $2^{\text {nd }}$ Co-author: Arturo, Curiel-Anaya / ORC ID: 0000-0002-9383-3452, Researcher ID Thomson: P-6718-2018, CVU CONACYT ID: 255222

ID $3^{\text {rd }}$ Co-author: David, Hernández-Sánchez / ORC ID: 0000-0002-0328-303X, Researcher ID Thomson: P-6717-2018

DOI: 10.35429/JTD.2021.16.5.13.21

Received June 15, 2021; Accepted December 30, 2021

\begin{abstract}
Instructional design has been integrated not only in processes for the generation of didactic materials oriented to education but also in other types of projects oriented to industry, the health sector, commerce, etc., where planning is reflected of solving a problem that involves a process of teaching or learning knowledge. This article presents the process of developing a mobile application using as a basis the implementation of the Jonassen Instructional Design model. Being a constructivist model, the reader will be able to observe how diverse knowledge of various methodologies are integrated, such as the Snowflake that is well structured and focuses on planning and creating novels, and the OOHDM that is oriented to the development of web applications using elements of hypermedia, so that in the end you get a useful and versatile mobile application that you can download freely from the Google Play Store.
\end{abstract}

\section{Resumen}

El diseño instruccional se ha venido integrando no solo en procesos para la generación de materiales didácticos orientados a la educación si no también en otros tipos de proyectos orientados a la industria, el sector salud, comercio, etc., en donde se vea plasmada la planificación de la solución de un problema que implique un proceso de enseñanza o aprendizaje de un conocimiento. En este artículo se presenta el proceso de desarrollo de una aplicación móvil utilizando como base la implementación del modelo de Diseño Instruccional de Jonassen. Siendo un modelo constructivista, el lector podrá observar cómo se integran diversos conocimientos de varias metodologías, tales como la Snowflake que esta bien estructurada y se enfoca a la planificación y creación de novelas, y la OOHDM que se orienta al desarrollo de aplicaciones web utilizando elementos de hipermedia, para que al final se obtenga una aplicación móvil útil y versátil que podrá descargar de la Play Store de Google en forma libre.

Diseño Instruccional, Modelo Jonassen, App Technological Development. 2021. 5-16:13-21.

\footnotetext{
$\dagger$ Researcher contributing first author.
} 


\section{Introduction}

This research and development project arises from the pleasure and desire to write a first novel. Considering not having the discipline to write, nor the knowledge of how to structure and plan a novel, as well as the desire to assess the effectiveness of the use of the Jonassen Model in the development of a mobile application (App). As those involved in the development of applications or information systems will advise, projects are usually integrative projects of diverse knowledge and therefore the Snowflake method was applied to write novels within a variety of methods such as "The Thirty Scenes", "Braindumping" or "Zero Draft", (Armedu, 2016), (Campbell, 2019), (Ingermanson R. , 2019), the above due to its way of structuring, for its ease of assimilating the idea of planning a novel and once planned, to be able to develop it in full. Finally, the OOHDM methodology was applied which allows planning both the backend and the frontend, that is, views and interfaces are considered with the user. A type of mobile programming based on Java Script and Android was also used utilizing the Ionic V4 development platform, which has the feature of being flexible when implementing the application both on a mobile device, as on a desktop computer and can be used anywhere at any time where there is internet.

\section{Jonassen Model application}

In many of the educational programs, students are asked to prepare a final project, a project to conclude the bachelors program, or a thesis. This projects allow the student to develop skills and abilities for their professional performance. Therefore the student or professor must propose an integrative project in which the skills acquired during their career are reflected.

The present project is based on a challenge, desire or concern to develop a tool to facilitate the writing of a novel, but at the moment of wanting to achieve that goal, questions begin to arise about the need to have acquired certain previous knowledge, what makes questioning the feasibility of solving the problem, knowledge ranging from maturity in programming, use of technological tools, to development methodologies and the lack of skills to write a novel.
So far, it is only the desire to develop a useful tool and the idea of being able to acquire the necessary knowledge in the course of the project. However, the desire or the idea of being able to assimilate a knowledge, to make it own, is a typical characteristic of constructivist models.

Several questions that need to be resolved before embarking on development begin to appear such as: Is there a model that can guide me with so many shortcomings? , Is that model enough?, Is there a willingness to learn new tools? , Will I be able to achieve my goal? In the face of such questions it is best to organize ideas and plan tasks, so a model of instructional design was selected, a model that will help us to detail and clarify ideas in a free way but without losing the goal, therefore the Jonassen Instructional Design model was chosen, (Belloch, 2017), (Lagunes, Diaz, \& Guerrero, 2014), (Vergel, 2021), which shall be described below and in accordance with the activities of the project.

- Phase 1: Questions / cases / problems / projects.

\section{- $\quad$ Phase 2: Related cases.}

- Phase 3: Information resources.

- $\quad$ Phase 4: Cognitive tools.
- Phase 5: Conversation / Collaboration tools.

\section{- $\quad$ Phase 6: Social /Context support.}

\section{Phase 1: Questions/cases/problems/projects}

Initially it must be clear what the main problem to solve, there must be sufficient motivation to set the objectives, so that in the end we can assess whether the project is functional according to the stated objectives.

The question, problem or project that arises must be attractive enough to motivate participants to get involved in the project, to make the problem their own, so that participants are willing to explore new tools, to look for similar proposals, or different from those initially proposed in order to obtain the best result. 
In the first phase, the creation of a question, case, problem or project must be proposed, which in turn will be part of the objective. For the project that we present, in this phase the development of a mobile application is proposed that facilitates the creation of a sketch of novel.

The process of creating a novel can be long and exhausting, in which you can have a fleeting idea in your mind, little fragments rambling, and yet you still don't have a structure that gives you a view of it, that is why methods are often used to plan a novel.

The questions that arise are: Can we make a mobile app that helps the planning of a novel? How can we build it?, Is there a method of planning novels?.

The App today is a tool that we have at our fingertips, this because you can find a large number of cell phones among the population. That is why the creation of a mobile app to perform this task is proposed, that allows users to create their novel from scratch, integrating a planning method. After questioning and visualizing the problem, the objectives can be set.

The objective is: To develop and provide an App as a useful tool, that serves as an aid to the creation of a sketch novel that is attractive to users.

\section{Phase 2: Related cases}

At this stage it is considered to look for cases related to the problem to be solved. The search for examples or similar cases makes it possible to acquire heuristic knowledge based on analogies, knowledge that will allow reasoning or procedures to be deduced and subsequently applied to new or similar situations.

At this point they looked for the types of writers, the methods that are commonly used to write a novel and the systems or technological tools that help the writer to plan the novel.

Within the types of writers, three categories were found: compass writers, map writers and hybrids.
Some methods to plan and write a novel are: traditional, of the three acts, hero trip, zero draft, of the three cubes, of the 30 scenes, braindumping and snowflake.

There are native applications that only run according to the operating system that have the mobile either Android or iOS, there are also applications that run on the computer according to your operating system such as Windows, Linux or MacOs. Among the applications that are used for this approach are usually varied, both for mobile and computers, so the development of a hybrid application was chosen, which can be run on various operating systems.

The tools that are available for desktop are those that must be previously installed on a computer, and viewing on that device is only allowed as long as the progress is saved in a local file, while mobile applications, that are installed on our mobile device, usually files are saved in the cloud.

Below are some of the applications found related to the project:

$\begin{array}{llll}- & \text { iAwritter } & - & \text { Focus Writter } \\ \text { - } & \text { Ulysses } & - & \text { Bibisco } \\ \text { - } & \text { StoryPlanner } & - & \text { Manuskript } \\ \text { - } & \text { yWriter } & - & \text { Jotterpad } \\ - & \text { Plume Creator } & - & \text { Scrivener }\end{array}$

There are few software applications that are available for both mobile devices and computers, and the only ones that usually include a planning method within their operation are Manuskript, StoryPlanner and Bibisco, as shown in Figure 1, (BigThink, 2019), (Feccomandi, 2019).

\begin{tabular}{|c|c|c|c|c|c|c|}
\hline \multirow{3}{*}{$\begin{array}{c}\text { Software } \\
\text { name }\end{array}$} & \multicolumn{3}{|c|}{ Software } & & & \multirow{2}{*}{$\begin{array}{l}\text { Planning } \\
\text { Method }\end{array}$} \\
\hline & \multicolumn{2}{|c|}{ Mobile } & \multicolumn{2}{|c|}{ Application } & Web & \\
\hline & Android & iOS & Windows & MacOS & & \\
\hline ¡Escribelo! & $\mathrm{x}$ & & & & $x$ & $x$ \\
\hline iAwriter & $x$ & $x$ & $x$ & $x$ & & \\
\hline Ulysses & & $x$ & & & & \\
\hline Story Planner & & $x$ & & & & $x$ \\
\hline yWriter & $x$ & $x$ & $x$ & $\mathrm{x}$ & & \\
\hline Plume Creator & & $x$ & $x$ & & & \\
\hline Focus Writer & & & $x$ & $x$ & & \\
\hline Bibisco & & & $x$ & $\mathrm{x}$ & & $x$ \\
\hline Manuskript & & & $x$ & $x$ & & $x$ \\
\hline Jotterpad & $x$ & & & & & \\
\hline Scrivener & & $x$ & $x$ & $x$ & & \\
\hline
\end{tabular}

Figure 1 Comparative table of applications for writing novels 


\section{Phase 3: Information resources}

This requires a more detailed understanding of the problem, and for this we ask: Who can provide us with this information?, How can I get the information?, What is the profile of the users?

It requires direct information from users, and what better than asking experienced writers, that is why information is collected from surveys of different writers that were presented at the University Book Fair organized by the Autonomous University of the State of Hidalgo. Part of the survey is shown in Figure 2, in which the result of the question that was asked is highlighted, "What technological tool did you use during the development of your last work?", $90 \%$ responded that the most commonly used tool is Word, the other 10\% used Scrivener. When questioned about the reason they used to use this software their response was for ease and sometimes because they did not know a different software, (Chimal, 2019), (Quezada, 2020), (Valderrama, 2019).

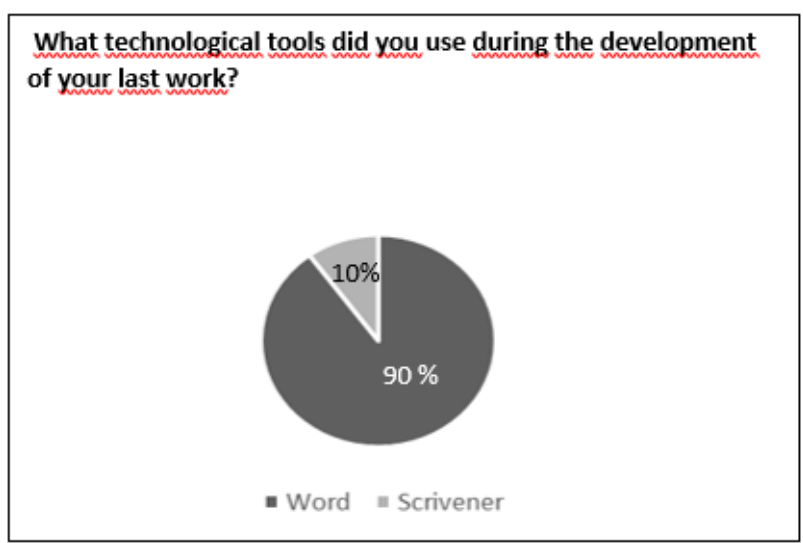

Figure 2 Graphic of the technological tools used by writers

According to this question it can be understood that writers do not usually use other type of software for lack of knowledge, rather because of a lack of attraction to new technologies and sometimes the experience they have gained over the years only uses basic tools such as word processors. Perhaps they focus their attention on the creative process and minimize new tools. However, this does not usually happen with beginning writers or people who start to venture into this area.

\section{Phase 4: Cognitive tools}

Each project has a specific cognitive demand, which can be simple or complex, for which the trainee or developers have or do not have, to a greater or lesser degree, the appropriate competencies, which must first recognize themselves and then know how to apply with proficiency. The predominant cognitive demand must be identified, because there can be multiple demands. For example, in this project you have two demands, one is how to write a novel and the other is how to develop the App. For this project, technological demand predominates. Thence in this phase more time and effort was spent in the search and knowledge of informatics or computer tools that allow visualizing and modeling the Snowflake method.

For the development of this phase, different points were analyzed, such as the planning methods that exist, the frameworks and development environments for mobile applications, as well as the databases that can be integrated within mobile applications.

For the methods that allow the planning of a novel, were found those with information resources, well organized, in addition to the sustenance that counts for its authors, such as books or blogs focused on novel writing, (BigThink, Las mejores aplicaciones móviles para guinistas y escritores., 2019), (Feccomandi, Aplicación de escritorio, 2019), (Ingermanson R. , The Snowflake Method For Designing A Novel, 2019) these methods are the following:

\section{- Thirty Scenes Method by C.S Lankin}

\section{- Braindumping Method by Chandler Bolt}

- Snowflake Method by Randy Ingermanson

Among these planning methods, the Snowflake Method was chosen, which has ten steps, among which the following points can be outlined:

- $\quad$ Have a well-defined plot of the novel.

- The creation of well-structured characters, this means that they must have the characteristics and history clearly reflected.

- $\quad$ Sequence of events within the novel.

QUEZADA-ARGUIJO, Alondra Jacquelinne, POZASCÁRDENAS, Mariano Javier, CURIEL-ANAYA, Arturo and HERNÁNDEZ-SÁNCHEZ, David. Exergy analysis of the absorption refrigeration cycle using economizers. Journal of Technological Development. 2021 
These three points form one of the fundamental parts during the process of planning and creating a novel.

For the choice of the development environment of the mobile application, it can be native, hybrid or web-oriented, that is why it was selected to choose the hybrid application, which allows the generated application to be targeted not only to a single mobile operating system, but also to be accessed through a web browser.

Among the tools that allow us to generate these applications are the following:

- $\quad$ React Native.

- $\quad$ Flutter.

- $\quad$ Ionic.

For the integration of the database, it is necessary to take into account the time and scope you want to obtain with this application, based on the following tools:

$-\quad$ MySql.
- $\quad$ SQLite.

- $\quad$ MongoDB.

Firestore de firebase.

For the choice of development tools, previous knowledge, the possible learning curves and the scope of the project were taken into consideration, which is why the selected tools are:

- Ionic: this framework in its version 4, allows the generation of hybrid applications, which results in the final application could be run on mobile devices with Android, iOS, operating system and web browsers (AndroidDeveloper, 2020), (Griffith, 2019), (Studio, 2019).

Firebase: Firebase: this API allows us to develop projects in an agile way. In addition it allows us to integrate Firebase Cloud Firestore (NoSQL database), Firebase Authentication (authentication) and Firebase Hosting (web storage), among others, (GoogleDevelopers, 2020) .
This phase focused on the development of the application, OOHDM methodology was incorporated integrating hypermedia. This methodology as a tool allows to make a visual representation of the snowflake method.

The OOHDM proposes four stages, each consecutive from the previous one, this methodology allows designers or developers to specify the running of the application, the stages are the following, (Vilariño, 2010):

- Conceptual design.

- Navigational design.

- $\quad$ Interface design.

- Implementation.

\section{Conceptual design}

The conceptual design consists of representing two types of objects, those that will be perceived as nodes in the navigation model and those that support the application, encapsulating behaviors such as algorithms, databases, etc. (Schwabe \& Rossi, 2019). Figure 3 shows the conceptual design of the application.

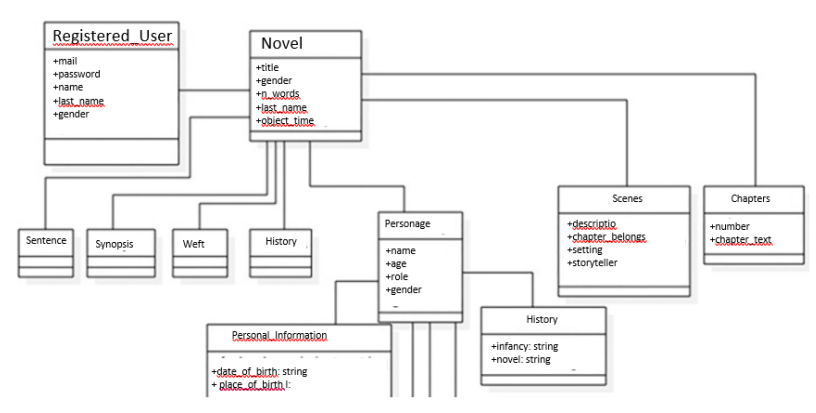

Figure 3 Diagram of Stage 1: Conceptual Design

\section{Navigational design}

For navigational design it is taken as a reference the conceptual design, this stage serves to reorganize the information and the it will way be displayed to users.

In this stage, class and context diagrams are integrated. In this way you can establish the possible views through predefined classes, also called navigational classes, these integrate: nodes (information containers) and links (relationship in navigation). 
In Figure 4, the class diagram made for this application is shown.

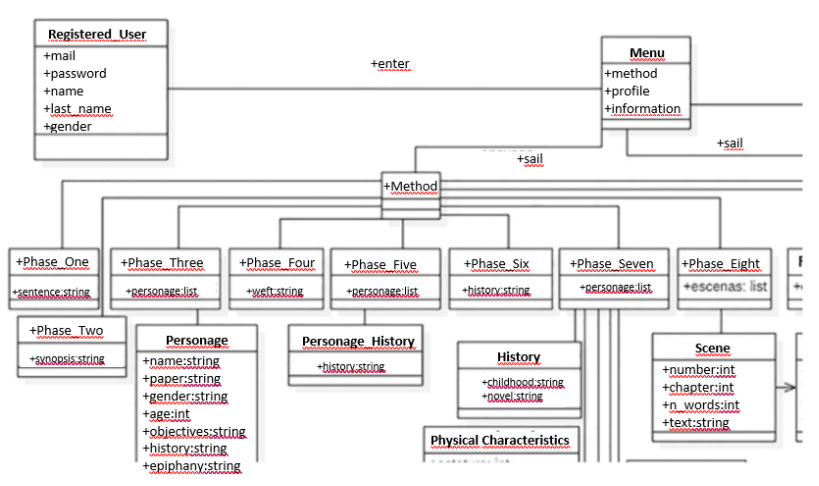

Figure 4 Diagram of Stage 2: Navigational Class Design

Since it allows us to show the links available once an object is accessed, in this case a node in a context, the context diagram is shown in Figure 5, characterized by showing in a more precise way how the navigation will be within the application.

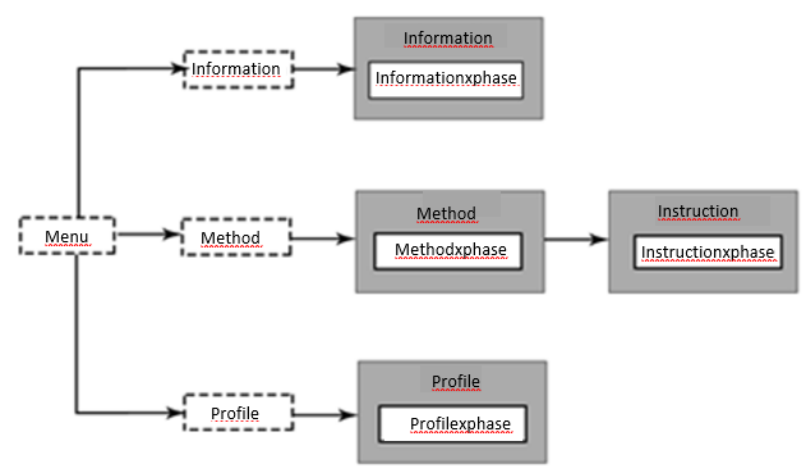

Figure 5 Diagram of Stage 2: Navigational Class Design

\section{Interface design}

This stage defines how objects will be presented through the user interface, appearance and distribution. It is important to note that at this stage the objects that are responsible for mediating the user's interaction with the navigation objects are specified.

The application is divided into three main sections: method, planning and profile. These can be seen at the bottom of the Figure 6 .

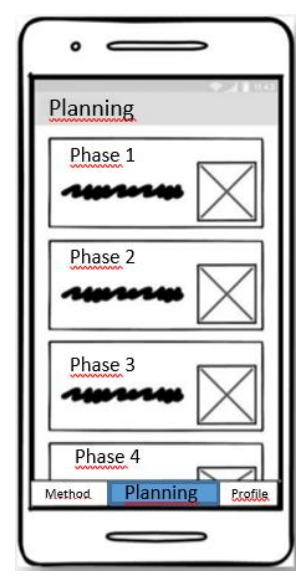

Figure 6 Application interface

\section{Implementation}

Supported by the selected designs and tools, the App was developed and shown in Figure 7, which can be used for Android and iOS operating systems, and this type of application can be run from any web browser.

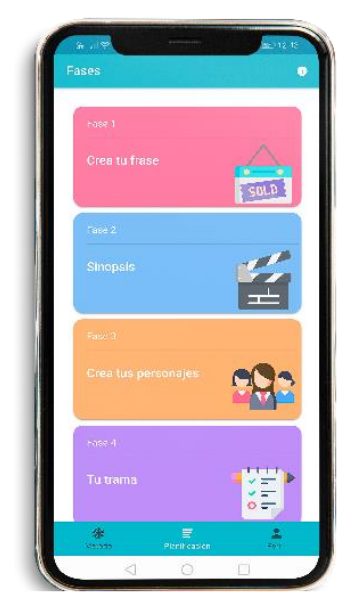

Figure 7 Final view of the application interface

Figure 8 shows some of the logos of the tools used for this project.

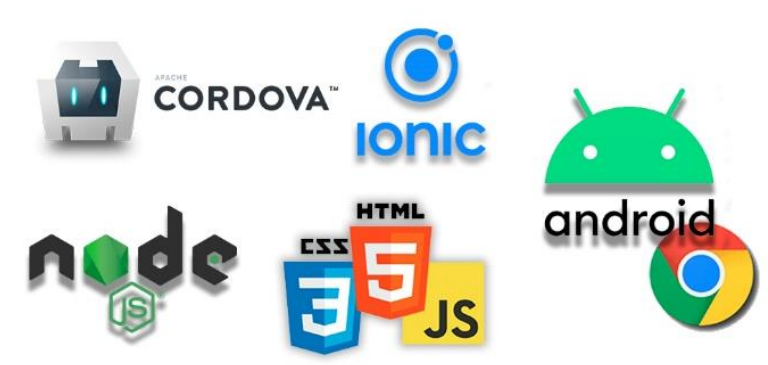

Figure 8 Tools used for application development 


\section{Phase 5: Conversation / Collaboration tools}

The work and learning environments are supported by ICT to facilitate the work of development, review, discussion and improvement, in short, a collaborative work.

In this new normality in which mobility has been restricted, it is important to promote communication through the computer tools available to us.

During the development of the project, the following tools were necessary:

- GitHub and Reply: Allow you to upload projects and maintain a version control, which in turn are synchronized both in the cloud and in our computer.

Google Drive: The use of this tool allowed the storage of documents and information.

Google Forms: For the storage and distribution of forms or surveys, which were submitted for the System Evaluation.

Google Play Store: For storage and distribution of the app for mobile devices with Android operating system.

Firebase: Data storage through your API.

The use of these tools allowed communication and collaboration by sharing information, experiences, work between the people involved in the development of this project and the people who have evaluated the application.

\section{Phase 6: Social /Context support}

One of the goals was to create a useful tool for the planning of novels, so, the best option to fulfill the social phase was to make it available for free so that they will use it and evaluate it, so it was published in the Google Play Store, (GoogleDevelopers, 2020) .

The above could be verified through the graphs and statistics of downloads not only at the locallevel, but also internationally as shown in Figure 9, in addition to the comments of acceptance of the writers who had participated in the first survey.

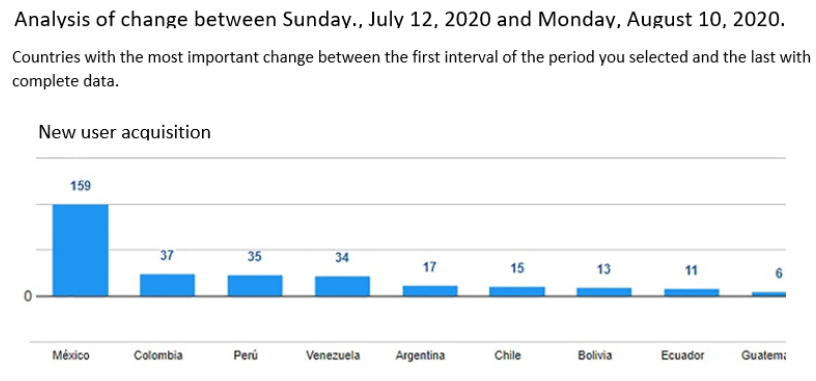

Figure 9 New User Adjection Chart for the App in the

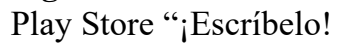

The application was tested by sixty users, who were provided with the links of the application and the form in which they expressed their views and assessments.

\section{Results}

The main results obtained are (Quezada, Tesis, 2020)

A mobile application was created as a technological aid for the planning of a novel, following Jonassen's Instructional Design model.

- For the sketch of the novel was implemented the method of planning and creation of novels Snowflake and for the design of the user interface was carried out following the methodology OOHDM. Figure 10 shows a final view of the application on various devices.



Figure 10 View of the application via mobile devices, tablet and desktop PC

Since the Jonassen Instructional Design model allowed the analysis and incorporation of ideas from different areas such as the Snowflake planning method, or the OOHDM methodology to construct the application, we can say that the Jonassen model is useful in the development of integrative projects. 
The app is available in the Play Store under the name "iEscribelo!", for which before publication you had to pass quality tests by Google. Figure 11 shows the logo of the application "iEscribelo!" which means "Write it!" in Spanish (GoogleDevelopers, 2020).

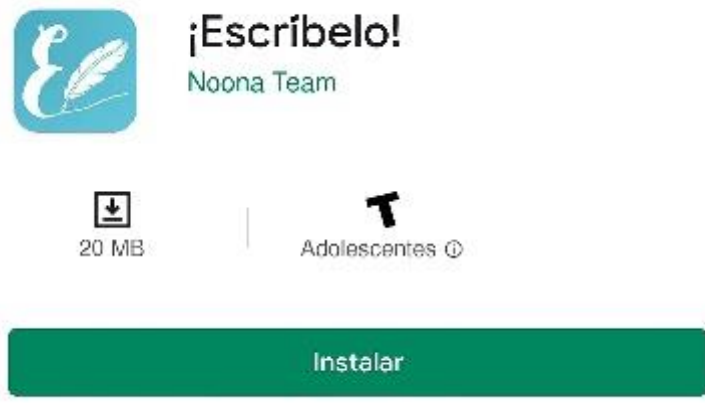

Figure 11 Publication of the application “Escribelo!” in Play Store

The percentage of downloads has been increasing as shown in Figure 12.

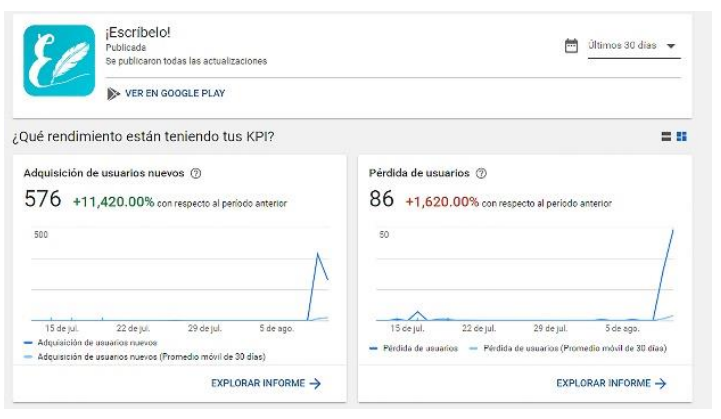

Figure 12. Statistics on the acquisition of new users in the Play Store

\section{Conclusions}

Several of the characteristics of the Jonassen model were found, such as: a). Development of autonomous skills of the participants since it is a constructivist model. b). Learning - doing allows one to acquire solid and meaningful knowledge. c). The use of new tools, which can be applied in future projects.

Having planned an attractive, useful and current challenge/project allows to encourage not only the reflection, search, assimilation and acquisition of a knowledge, but also the adaptation of ideas and concepts of other people to the problem to be solved, thus encouraging the creation of meta-knowledge for the participants involved.
- The use of information and communication technologies, applied to the development of novel planning, has proved to be a paradigm for exploiting resources in the cloud and on the web, in favor of the current demands of the demanding society.

In relation to future work, the application has a growth potential in which complementary topics to the writing of novels can be addressed such as the incorporation of new planning methods, and even addressing new genres of writing, as the production of theatrical scripts, among others. Being an opportunity for the incorporation of new projects, the technological tools that at the time appear such as: new development platforms.

\section{References}

AndroidDeveloper. (30 de 06 de 2020). Android Studio 3.6. Obtenido de Android Studio 3.6: https://androiddevelopers.googleblog.com/2020 /02/android-studio-36.html

Armedu, M. (08 de 09 de 2016). La estructura de los tres actos:planeando una novela de como escribir una novela. Obtenido de http://comoescribirnovelas.com/articulos/novela -con-la-estructura-los-tres-actos/

Belloch, C. (2017). Diseño Instruccional. UTEUV, 15.

BigThink. (30 de 09 de 2019). Las mejores aplicaciones móviles para guinistas y escritores. Obtenido de https://tecno.americaeconomia.com/resenas/lasmejores-aplicaciones-moviles-paraguionistas-yescritores

Campbell, G. (6 de 11 de 2019). 7 Métodos probados para planificar tu novela. Obtenido de https://www.gabriellaliteraria.com/planificartu-novela/

Chimal, A. (25 de 08 de 2019). Herramientas técnologicas que son utilizadas por los escritores. (Q. A. Jacquelinne, Entrevistador)

Feccomandi, A. (30 de 06 de 2019). Aplicación de escritorio. Obtenido de https://bibisco.com 
GoogleDevelopers. (25 de 01 de 2020). Firebse Hosting. Obtenido de https://firebase.google.com/docs/hosting/usecases?hl=es-419

Griffith. (06 de 30 de 2019). IonicFramework. Obtenido de https://ionicframework.com/resources/articles/ what-is-apachecordova

Ingermanson, R. (6 de 8 de 2019). The Snowflake Method For Designing A Novel. Obtenido de https://www.advancedfictionwriting.com/article s/snowflake-method/

Lagunes, A., Diaz, J., \& Guerrero, H. (30 de 01 de 2014). Modelo de DIseño de Entornos de Aprendizaje Constructivista EAC. Obtenido de https://www.researchgate.net/publication/27398 7291

Quezada, A. A. (21 de 10 de 2020). tesis. Bosquejo de Novela con Dispositivos Moviles Utilizando la Metodología Jonassen. Mineral de la Reforma, Hidalgo, México: 10.

Schwabe, D., \& Rossi, G. (1 de 11 de 2019). An Object Oriented Approach to Web-Based Application Design. Brazil: TAPOS. Obtenido de

http://citeseerx.ist.psu.edu/viewdoc/download?d oi $=10 \cdot 1 \cdot 1 \cdot 70.4427 \&$ rep=rep $1 \&$ type $=$ pdf

Studio, I. (30 de 06 de 2019). Ionic Studio. Obtenido de https://ionicframework.com/studio

Valderrama, H. (26 de 08 de 2019). Herramientas Tecnologicas que son utilizadas por los escritores. (Q. A. Jacquelinne, Entrevistador)

Vergel, B. (11 de 06 de 2021). Diseño Instruccional, Teória del aprendizaje, Universidad de Saskatchewan. Obtenido de https://orion2020.org/archivo/docencia/08\%20 DI.pdf

Vilariño, J. (19 de 05 de 2010). Modelo para la elección de la metodología de desarrollo web de una aplicación según sus características funcionales. Obtenido de http://biblioteca2.ucab.edu.ve/anexos/biblioteca /marc/texto/AAS2255.pdf
QUEZADA-ARGUIJO, Alondra Jacquelinne, POZASCÁRDENAS, Mariano Javier, CURIEL-ANAYA, Arturo and HERNÁNDEZ-SÁNCHEZ, David. Exergy analysis of the absorption refrigeration cycle using economizers. Journal of Technological Development. 2021 